\title{
Induction of Petite Mutation in Yeast by Starvation in Glycerol
}

\author{
By O. CARYL WALLIS AND P. A. WHITTAKER \\ School of Biological Sciences, University of Sussex, \\ Falmer, Brighton BNI $9 Q G$
}

(Received I2 November 1973; revised 24 April 1974)

S UMMAR Y

\begin{abstract}
Starvation of baker's yeast, Saccharomyces cerevisiae, in $2 \%$ glycerol induces high levels of petite mutants. The rate of mutation is highest when exponential phase cells are used to inoculate the starvation medium. The starved cells are exceedingly sensitive to ethidium bromide mutagenesis. Cycloheximide and sodium nalidixate enhance starvation-induced mutation (although nalidixate reduces the ethidium bromide induction). Starvation-induced mutation is inhibited by rifampicin or erythromycin. The appearance of petite mutants is preceded by a fall in both $Q_{\mathrm{O}_{2}}$ and mitochondrial DNA.
\end{abstract}

\section{INTRODUCTION}

Considerable interest is shown in the cytoplasmically-inherited petite mutation in the yeast Saccharomyces cerevisiae. Petite mutants exhibit multiple deficiencies in mitochondrial function and it is established that the primary lesion is in mitochondrial DNA. This may be either grossly altered in base composition (Mounolou, Jakob \& Slonimski, 1966) or totally lost (Moustacchi \& Williamson, I966). Generally, yeast cultures maintain levels of $0 . \mathrm{I}$ to $\mathrm{I} \cdot 0 \%$ petite mutants which have arisen spontaneously. It is possible to raise this level to $100 \%$ petite mutants by growing the yeast in the presence of ethidium bromide, acriflavine, 5-fluorouracil or erythromycin. Wallis, Ottolenghi \& Whittaker (1972) have recently reported that high levels of petite mutants can be induced in the absence of a mutagenic drug when yeast cells are incubated in $2 \%$ glycerol. This lability of the mitochondrial genome was not associated with any apparent damage to the nuclear genome. The characteristics of the mutation process are reported.

\section{METHODS}

Yeast strain and growth conditions. The diploid, prototrophic strain of Saccharomyces cerevisiae, NCYC239, was used in all experiments; NCYC283 (diploid) and NCYC295 (haploid) were also used. Liquid and agar growth media used were those described by Luha, Sarcoe \& Whittaker (I97I). A working stock was prepared as follows: a loopfull of yeast from an agar slope was inoculated into Io $\mathrm{ml}$ glucose yeast liquid medium (Luha et al. I97 I) and incubated at $30{ }^{\circ} \mathrm{C}$ without shaking for $16 \mathrm{~h}$. An appropriate volume of this culture was used to inoculate a further $10 \mathrm{ml}$ of the glucose yeast liquid medium to a concentration of $4.5 \times$ $10^{4}$ cells $/ \mathrm{ml}$ and again incubated at $30{ }^{\circ} \mathrm{C}$ without shaking for $\mathrm{I} 6 \mathrm{~h}$ before storage at $4{ }^{\circ} \mathrm{C}$ for up to 7 days. Inocula prepared in this way gave reproducible growth on glycerol yeast liquid medium (Luha et al. I97I). For the mutation experiments 50 or $250 \mathrm{ml}$ yeast liquid medium in $250 \mathrm{mI}$ or 21 conical flasks respectively were inoculated from the working 
stock at $6 \times 10^{3}$ cells $/ \mathrm{ml}$ and incubated at $30^{\circ} \mathrm{C}$ in a rotary shaking incubator (Gallenkamp $\mathrm{Ltd}$ ) at $300 \mathrm{rev}$. $/ \mathrm{min}$ until the cell density was between $6 \times 10^{6}$ and $8 \times 10^{6} \mathrm{cells} / \mathrm{ml}$ (unless otherwise stated). The cells were harvested by centrifugation at room temperature, washed twice in sterile distilled water ( $10 \mathrm{ml} / 2 \times 10^{8}$ cells) and then inoculated at between $6 \times 10^{6}$ and $8 \times 10^{6}$ cells $/ \mathrm{ml}$ (unless otherwise stated) into either 50 or $250 \mathrm{ml} 2 \%$ glycerol and incubated at $30{ }^{\circ} \mathrm{C}$ in a rotary shaking incubator at $300 \mathrm{rev} . / \mathrm{min}$. Additions were made to the $2 \%$ glycerol solution as indicated, the $\mathrm{pH}$ being readjusted if necessary to 5.5 .

Some variation in mutation kinetics between experiments was observed even when growth conditions were carefully controlled. However, within a single experiment good agreement between duplicates was always obtained. Consequently, to validate the conclusions drawn from the data shown in individual tables or figures, each of these contains data taken from the results of a single experiment although the data are qualitatively typical of a number of such experiments.

Measurement of petite mutation. This was determined by removing samples of the starved cells at intervals, diluting in sterile distilled water and plating duplicate samples (approximately 150 cells) onto glucose agar plates (Luha et al. 197I). Colonies were grown at $30{ }^{\circ} \mathrm{C}$ for 3 days and were then overlaid with $\mathrm{I} \%$ agar containing $0.05 \% 2,3,5$-triphenyltetrazolium chloride and $0.5 \%$ glucose (Ogur, St. John \& Nagai, 1957), when normal colonies appear red and petite colonies white.

Measurement of oxygen consumption. Samples of the suspensions in $2 \%$ glycerol were removed at intervals, the cells harvested by centrifugation and resuspended in fresh $2 \%$ glycerol before measurement of oxygen uptake with a Clark-type oxygen-electrode (Rank Bros., Bottisham, Cambridge).

Preparation of DNA and analytical ultracentrifugation. At least $2 \times 10^{9}$ cells were harvested by centrifugation and washed twice in $10 \mathrm{ml}$ distilled water. DNA extracts were then prepared from the pellets by the method of Williamson, Moustacchi \& Fennell (I97I). Analytical isopycnic $\mathrm{CsCl}$ centrifugation of the extracts was carried out according to the method of Schildkraut, Marmur \& Doty (I962) using a Beckman Model E analytical ultracentrifuge equipped with a four-cell rotor and u.v.-absorption optics. Negatives were scanned with a Joyce-Loebl recording microdensitometer. Buoyant densitities were computed according to Sueoka (196I) using as reference Micrococcus luteus DNA (buoyant density I $73 \mathrm{I} \mathrm{g} / \mathrm{cm}^{3}$ ).

\section{RESULTS}

\section{Factors affecting the petite mutation rate during starvation}

Age of inoculum culture. Initially considerable difficulties were encountered in achieving a reproducible mutagenesis. Small variations in the stage at which cells were harvested after growth in the glycerol liquid-medium before starvation resulted in large variations in the subsequent appearance of petite mutants. Figure I shows the effects of starving in glycerol, cells harvested at cell densities ranging from $3.0 \times 10^{6} / \mathrm{ml}$ (exponential growth phase) to $4.2 \times 10^{7} / \mathrm{ml}$ (transition from exponential to stationary phase). In each case the cell density during starvation was the same $\left(6 \times 10^{6} / \mathrm{ml}\right)$. Both the mutation rate per day and the final level of mutants decreased with increased age of the inoculum culture. No significant loss in viability occurred during the starvation period.

Nature of the starvation medium. The effects of different starvation media were studied (Table I). Replacement of glycerol with $2 \%$ glucose led to cell death. In distilled water or $0.2 \%$ ethanol viability was maintained and petite mutation did not occur. Similar results have been obtained with other yeast strains (NCYC283 and NCYC295). 


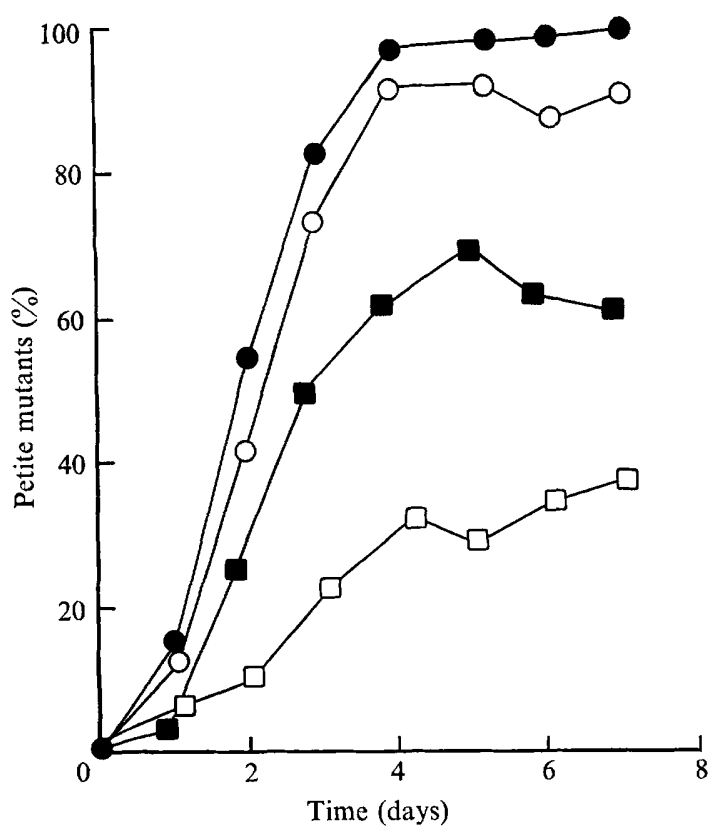

Fig. I. Effect of cell density in inoculum culture on the rate of petite mutation during starvation in glycerol. Cells were harvested from glycerol liquid medium at various densities: $0,3 \cdot 0 \times 10^{6} / \mathrm{ml}^{\circ}$ $0,5.0 \times 10^{6} / \mathrm{ml} ; \square, 1 \cdot 3 \times 10^{7} / \mathrm{ml} ; \square, 4.2 \times 10^{7} / \mathrm{ml}$. All were starved in $50 \mathrm{ml}$ of $2 \%$ glycerol at a cell density of $6.0 \times 10^{8} / \mathrm{ml}$. Otherwise growth, starvation and petite assay conditions were as in Methods.

Table I. Effects of various starvation media on petite mutation and cell viability

Cells were starved at $30^{\circ} \mathrm{C}$ in $50 \mathrm{ml}$ of the starvation media indicated for 6 days. Otherwise growth, starvation and petite assay conditions were as in Methods.

$\begin{array}{lcc}\begin{array}{c}\text { Starvation } \\ \text { medium }\end{array} & \begin{array}{c}\text { Petites } \\ (\%)\end{array} & \begin{array}{c}\text { Viable cells } \\ (\%)\end{array} \\ 2 \% \text { Glycerol } & 80 & 100 \\ 2 \% \text { Glucose } & - & 0 \\ 0.2 \% \text { Ethanol } & 0.4 & 100 \\ \text { Distilled water } & 1.0 & 100\end{array}$

Effect of starvation in glycerol on oxygen uptake. The oxygen uptake of cells was measured after periods of starvation in $2 \%$ glycerol. The $Q_{\mathrm{o}_{2}}$ was found to fall markedly before a significant increase in petite level occurred (Fig. 2). After $24 \mathrm{~h}$ incubation in glycerol there was a $40 \%$ loss of $Q_{\mathrm{O}_{2}}$ but only $6 \%$ of the cells gave rise to petite colonies.

Effects of nucleic acid and protein synthesis inhibitors. A number of these have been shown to affect chemically-induced petite mutation (Williamson, I970; Hollenberg \& Borst, 197I ; Whittaker \& Wallis, I97I; Vidova \& Kovac, I972; Whittaker, Hammond \& Luha, 1972; Whittaker \& Wright, 1972). The effects of some of these inhibitors on the petite induction by starvation in glycerol are reported below.

(i) Rifampicin (a gift from CIBA, Horsham). This is an inhibitor of RNA polymerase in prokaryotes (Ezekiel \& Hutchins, I968) and considerably enhances ethidium bromideinduced petite mutation (Whittaker \& Wallis, 197I). Figure 3 shows that rifampicin markedly reduces starvation-induced petite mutation. After 7 days' starvation in glycerol 


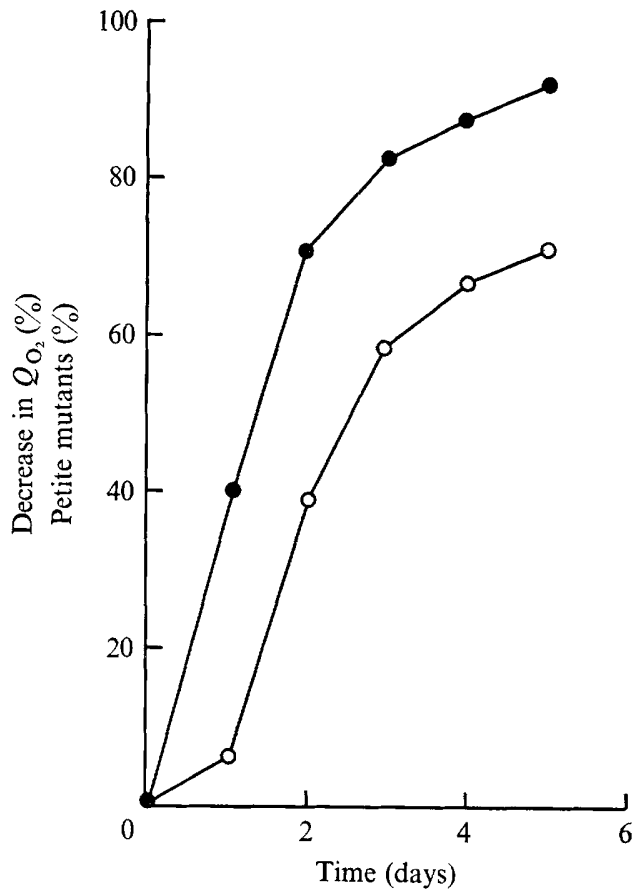

Fig. 2

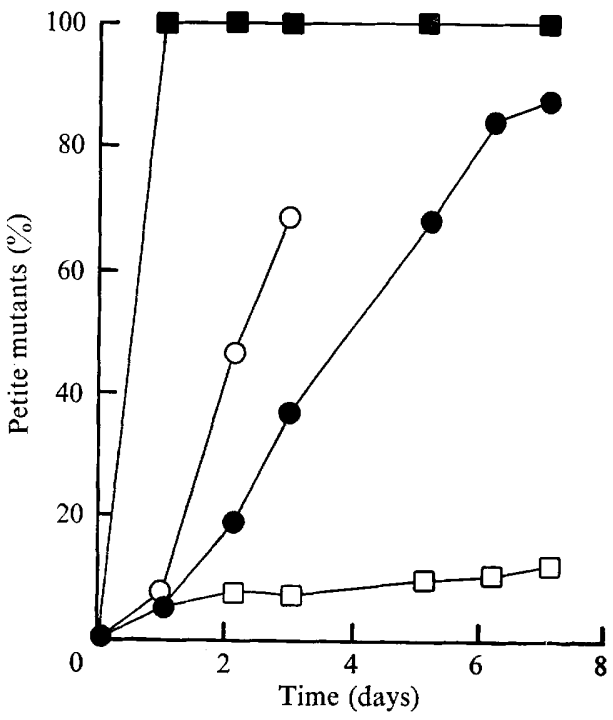

Fig. 3

Fig. 2. Effect of starvation in glycerol on $Q_{\mathrm{O}_{2}}$. Cells were harvested from yeast liquid medium at a cell density of $\mathrm{I} \cdot \mathrm{I} \times 10^{7} / \mathrm{ml}$ and starved in $250 \mathrm{ml}$ of $2 \%$ glycerol at a cell density of $1 \cdot 0 \times 10^{7} / \mathrm{ml}$. Samples were removed at the times indicated and assayed for $Q_{\mathrm{O}_{2}}$ and petite mutants. Otherwise growth, starvation, $Q_{\mathrm{O}_{2}}$ and petite assays were as in Methods.

Fig. 3. Effects of ethidium bromide, nalidixate and rifampicin on petite mutation during starvation in glycerol. Cells were harvested at a cell density of $5.8 \times 10^{6} / \mathrm{ml}$ and starved at a cell density of $5.1 \times 10^{6} / \mathrm{ml}$ in $50 \mathrm{ml}$ of $2 \%$ glycerol with the following additions: $\Theta$, no addition; $\mathbf{\square}$, ethidium bromide, $\mathrm{I} \mu \mathrm{g} / \mathrm{ml} ; O$, sodium nalidixate, $50 \mu \mathrm{g} / \mathrm{ml} ; \square$, rifampicin, $100 \mu \mathrm{g} / \mathrm{ml}$. Otherwise growth, starvation and petite assay were as in Methods. No significant results were obtainable after the 3 day time point with sodium nalidixate because of loss of cell viability.

Table 2. Induction of petite mutants by ethidium bromide during starvation in glycerol

Cells were starved for various periods at $30{ }^{\circ} \mathrm{C}$ in $2 \%$ glycerol $(50 \mathrm{ml})$ containing the indicated concentrations of ethidium bromide. Otherwise growth, starvation and petite assay conditions were as in Methods.

$\begin{array}{cccc}\begin{array}{c}\text { Ethidium } \\ \text { bromide } \\ \begin{array}{c}\text { concentration } \\ (\mu \mathrm{g} / \mathrm{ml})\end{array}\end{array} & \begin{array}{c}\text { Petite mutants }(\%) \text { after } \\ \text { starvation for }(\mathrm{h}):\end{array} \\ 0 & 0.3 & 5 & 24 \\ 0.05 & 16 & 0.3 & 4 \cdot 0 \\ 0.10 & 57 & 82 & 100 \\ 0.25 & 96 & 97 & 100 \\ 0.50 & 99 & 99 & 100 \\ \text { I.00 } & 99 & 100 & 100 \\ & & & 100\end{array}$

and rifampicin (I00 $\mu \mathrm{g} / \mathrm{ml}$ ) there were only $\mathrm{I} 2 \%$ petites compared with $87 \%$ in the absence of rifampicin. Rifampicin did not prevent the early loss of respiratory activity.

(ii) Sodium nalidixate [prepared by neutralizing nalidixic acid (Sigma) with $\mathrm{NaOH}$ ]. 


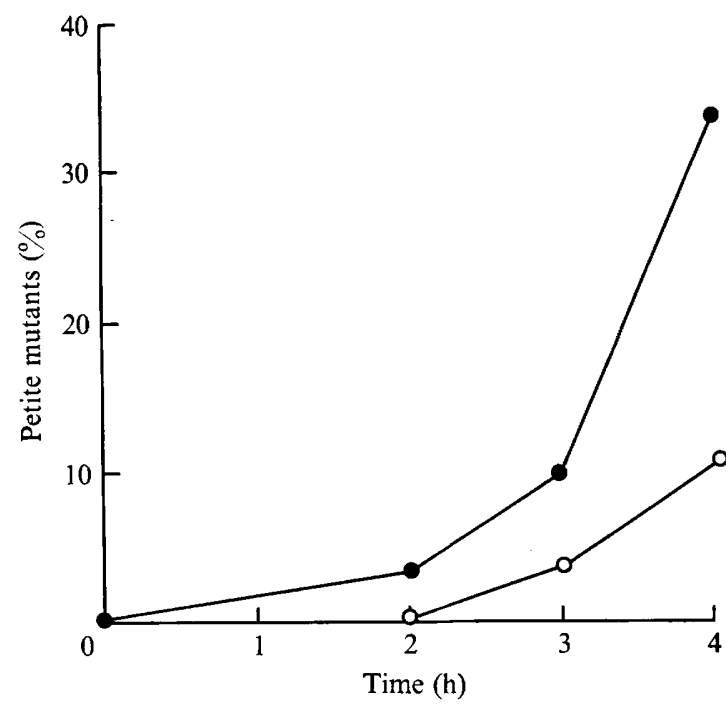

Fig. 4

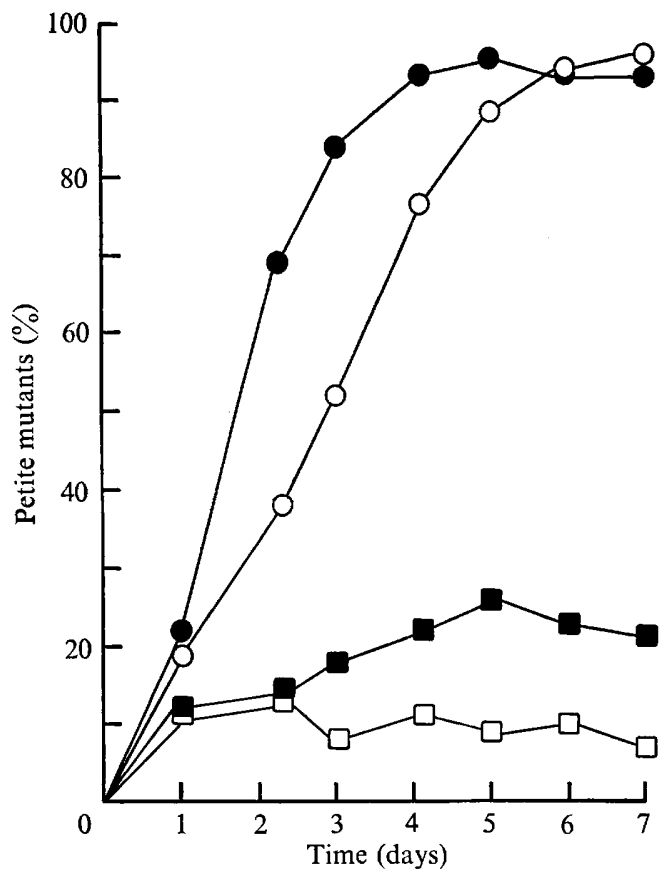

Fig. 5

Fig. 4. Effect of sodium nalidixate on ethidium bromide induction of petites during starvation in glycerol. Cells were harvested at a cell density of $6.5 \times 10^{6} / \mathrm{ml}$ and starved at a cell density of $6.6 \times 10^{6} / \mathrm{ml}$ in $50 \mathrm{ml}$ of $2 \%$ glycerol containing ethidium bromide $(0.05 \mu \mathrm{g} / \mathrm{ml})$, with the following additions: - , no addition; $\bigcirc$, sodium nalidixate, $10 \mu \mathrm{g} / \mathrm{ml}$. Otherwise growth, starvation and petite assay were as in Methods.

Fig. 5. Effect of erythromycin on petite mutation during starvation in glycerol. Cells were harvested at a cell density of $6.3 \times 10^{6} / \mathrm{ml}$ and starved at a cell density of $5.6 \times 10^{6} / \mathrm{ml} \mathrm{in} 50 \mathrm{ml} \mathrm{of} 2 \%$ glycerol with the following additions: $\bullet$, no addition; $\bigcirc$, erythromycin, $100 \mu \mathrm{g} / \mathrm{ml}$; $\mathbf{0}$, erythromycin, $200 \mu \mathrm{g} / \mathrm{ml} ; \square$, erythromycin, $400 \mu \mathrm{g} / \mathrm{ml}$. Otherwise growth, starvation and petite assay were as in Methods.

This is an inhibitor of DNA synthesis which inhibits petite mutation induced by ethidium bromide or 5-fluorouracil (Whittaker et al. 1972). This inhibitor (at $50 \mu \mathrm{g} / \mathrm{ml}$ ) increased the initial rate of petite mutation during starvation in glycerol (Fig. 3) but cells lost viability ( I $\%$ viable cells after 6 days of starvation).

(iii) Ethidium bromide (a gift from Boots Pure Drug Co., Nottingham). This drug acts as a powerful petite mutagen. Cells starved in glycerol were rapidly and completely converted to petite mutants in the presence of very low concentrations $(0.05$ to $\mathrm{r} \cdot 0 \mu \mathrm{g} / \mathrm{ml})$ of ethidium bromide (Table 2 and Fig. 3). The same strain is much less sensitive to ethidium bromide during normal growth (Whittaker et al. 1972). Rifampicin had no effect on the ethidium bromide-induced mutation whereas nalidixate delayed its appearance (Fig. 4).

(iv) Erythromycin (Sigma). Erythromycin is an inhibitor of mitochondrial protein synthesis in yeast and is a petite inducer (Williamson, Maroudas \& Wilkie, I97I). Erythromycin $(200 \mu \mathrm{g} / \mathrm{ml})$, like rifampicin, considerably reduced mutation in the system described here (Fig. 5).

(v) Cycloheximide (Koch-Light). This inhibitor of cytoplasmic protein synthesis also prevents the petite mutation induced by ethidium bromide or 5 -fluorouracil (Whittaker \& 


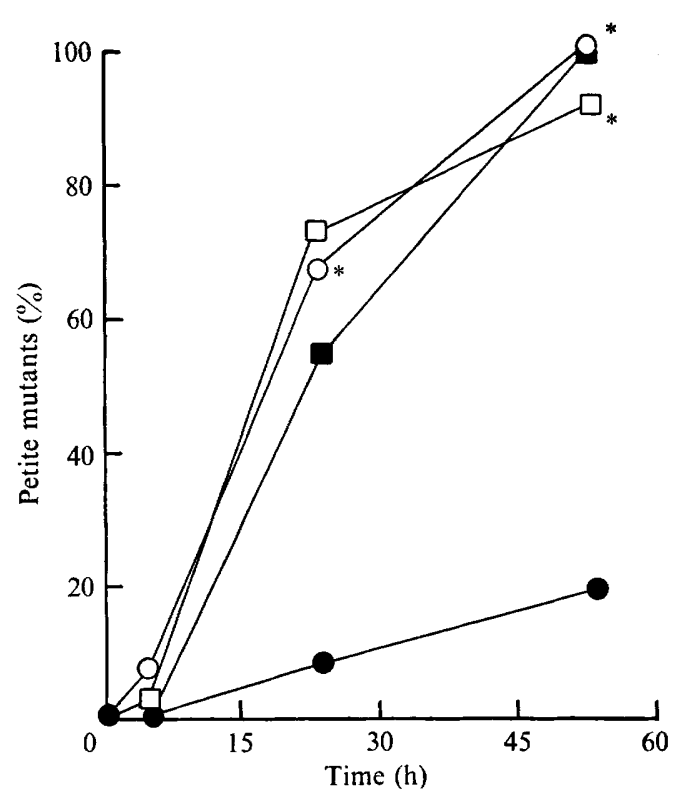

Fig. 6

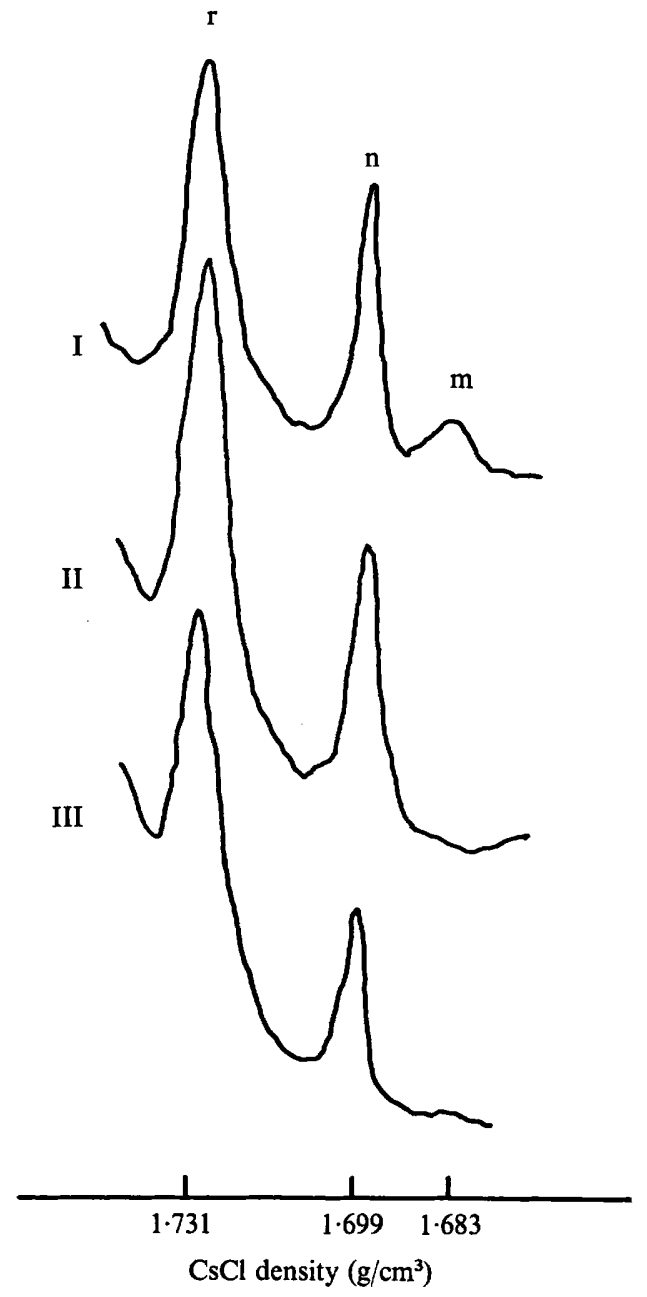

Fig. 7

Fig. 6. Effect of cycloheximide on petite mutation during starvation in glycerol. Cells were harvested at a cell density of $7.8 \times 10^{6} / \mathrm{ml}$ and starved at a cell density of $8.9 \times 10^{6} / \mathrm{ml}$ in $50 \mathrm{ml}$ of $2 \%$ glycerol with the following additions: 0 , no addition; $\square$, cycloheximide, $0.25 \mu \mathrm{g} / \mathrm{ml}$; $\square$, cycloheximide, $0.5 \mu \mathrm{g} / \mathrm{ml} ; 0$, cycloheximide, $\mathrm{r} \cdot 0 \mu \mathrm{g} / \mathrm{ml}$. Otherwise growth, starvation and petite assay were as in Methods. Significant loss of viability had occurred at points marked with an asterisk.

Fig. 7. Effect of starvation in glycerol in the presence and absence of ethidium bromide on yeast mitochondrial DNA. Cells were grown in glycerol yeast liquid medium to $\mathrm{I} \cdot \mathrm{I} \times 1 \mathrm{IO}^{7} / \mathrm{ml}^{\mathrm{a}}$ and harvested. DNA was extracted from a sample of these cells and subjected to analytical isopycnic $\mathrm{CsCl}$ centrifugation as described in Methods. Trace $\mathrm{I}$ is a densitometric recording of the u.v.absorption negative from this spin. The three peaks observed are labelled $\mathbf{r}$ for reference DNA (Micrococcus luteus DNA density $\mathrm{I} \cdot 73 \mathrm{I} \mathrm{g} / \mathrm{cm}^{3}$ added prior to centrifugation), $\mathrm{n}$ for nuclear DNA $\left(\mathrm{I} \cdot 699 \mathrm{~g} / \mathrm{cm}^{3}\right)$ and $\mathrm{m}$ for mitochondrial DNA $\left(\mathrm{I} \cdot 683 \mathrm{~g} / \mathrm{cm}^{3}\right)$. Samples of these cells were also starved at $7.0 \times 10^{6} / \mathrm{ml}$ in $250 \mathrm{ml}$ of $2 \%$ glycerol in the presence (trace II) and absence (trace III) of ethidium bromide, $5 \mu \mathrm{g} / \mathrm{ml}$. DNA was similarly extracted and analysed after $3 \mathrm{~h}$ starvation with ethidium bromide (trace II) or $24 \mathrm{~h}$ starvation without ethidium bromide (trace III). 
Wright, 1972). Cycloheximide $(0.25$ to $\mathrm{I} \cdot 0 \mu \mathrm{g} / \mathrm{ml})$ also emulated sodium nalidixate in the system studied, in increasing the initial rate of petite mutation and causing loss of viability, less than $10 \%$ viable cells remaining after $53 \mathrm{~h}$ (Fig. 6).

\section{Effects of starvation in glycerol on mitochondrial DNA levels}

DNA was extracted from normal cells and from cells which had undergone starvation in glycerol in the presence and absence of ethidium bromide. Microdensitometer scans of u.v.-absorption negatives from the extracts following isopycnic $\mathrm{CsCl}$ centrifugation showed that a mitochondrial DNA peak is clearly detectable in the normal cells, but is missing from cells starved in glycerol in the absence of ethidium bromide for $24 \mathrm{~h}$ or in the presence of ethidium bromide for three hours (Fig. 7).

\section{DISCUSSION}

Starvation of yeast cells in $2 \%$ glycerol led to petite mutation. This cannot be attributed solely to the absence of a nitrogen source, mineral salts or vitamins (cf. Nagai, 1969) as mutation did not occur when cells were starved in distilled water or $0.2 \%$ ethanol. The fall in mitochondrial DNA level prior to mutation indicated that mitochondrial DNA degradation was occurring. The rate of degradation must vary with the growth phase of the cells which are used as the starvation inoculum.

It is interesting that the effects of rifampicin, erythromycin, nalidixic acid and cycloheximide on starvation-induced mutation differed from those previously observed on mutation in growing cells, even though these inhibitors are reputed to be relatively specific in their effects at the concentrations that we employed.

The simplest explanation of the effects of erythromycin and rifampicin would be that a mitochondrial DNA-specified protein, synthesized on mitochondrial ribosomes, is responsible either directly or indirectly for the degradation of mitochondrial DNA during starvation in glycerol. In contrast, it has been suggested that a mitochondrially-synthesized protein prevents mitochondrial DNA breakdown in growing cells (Williamson et al. 1971). The cycloheximide and nalidixate effects are difficult to explain. The cycloheximide stimulation of mutation in starving cells described here is probably not related directly to the inhibition of ethidium bromide induction of petites in growing cells, as the former requires a 100 times greater concentration of cycloheximide than the latter. In the mutagenic process described in this report, it is possible that a protein synthesized on cytoplasmic ribosomes may modify the action of the protein postulated to promote mitochondrial DNA breakdown. Nalidixate emulates cycloheximide both in the starvation system and in ethidium bromide or 5-fluorouracil induction of petites. Although nalidixate is regarded as a relatively specific inhibitor of DNA synthesis its precise effect on the polymerase system is not established. It is not considered to be an inhibitor of yeast protein synthesis (Mounolou, 1967). A better knowledge of the precise action of nalidixate could add to our understanding of the mechanism of the petite mutation. At present one can only speculate that yeasts contain a complex control system for maintaining mitochondrial DNA levels. It seems likely that the mutation process described here results from a breakdown of this control system as a result of deficient and unbalanced nutrient supply.

The authors thank the Wellcome Trust and the Royal Society for supporting this work, and Mr L. E. Sarcoe and Miss M. Wright for skilled technical assistance. 


\section{REFERENCES}

EzekieL, D. H. \& Hutchins, J. E. (I968). Mutations affecting RNA polymerase associated with rifampicin resistance in Escherichia coli. Nature, London 220, 276-277.

Hollenberg, C. P. \& Borst, P. (I97I). Conditions that prevent $\rho^{-}$induction by ethidium bromide. Biochemical and Biophysical Research Communications 45, 1250-I 254.

Luha, A. A., Sarcoe, L. E. \& Whittaker, P. A. (197I). Biosynthesis of yeast mitochondria. Drug effects on the petite negative yeast Kluyveromyces lactis. Biochemical and Biophysical Research Communications 44, 396-402.

Mounolou, J. C. (1967). Role d'un ADN specifique dans le déterminisme genétique et physiologique des mitochondries de la levure. D.EsSc. thesis, Faculte des Sciences de Paris, France, pp. 86-89.

Mounolou, J. C., JАKoв, H. \& SLONIMSKi, P. P. (1966). Mitochondrial DNA from yeast petite mutants: specific changes of buoyant density corresponding to different cytoplasmic mutations. Biochemical and Biophysical Research Communications 24, 218-224.

Moustacchi, E. \& Williamson, D. H. (1966). Physiological variations in satellite components of yeast DNA detected by density gradient centrifugation. Biochemical and Biophysical Research Communications 23, 56-6I.

NAGAI, S. (1969). High-frequency production of respiratory mutants in yeast under nutritional deficiencies. Mutation Research 8, 557-564.

OGUR, M., St. JohN, R. \& NAGAI, S. (1957). Tetrazolium overlay technique for population studies of respiratory deficiency in yeast. Science, New York 125, 928-929.

Schildkraut, C. L., Marmur, J. \& Doty, P. (I962). Determination of the base composition of deoxyribonucleic acid from its buoyant density in CsCl. Journal of Molecular Biology 4, 430-433.

SuEOKA, N. (196I). Variation and heterogeneity of base composition of deoxyribonucleic acids: a compilation of old and new data. Journal of Molecular Biology 3, 3I-40.

Vidova, M. \& Kovac, L. (1972). Nalidixic acid prevents the induction of yeast cytoplasmic respiration deficient mutants by intercalating drugs. Federation of European Biochemical Societies Letters 22, 34735 I.

Waluis, O. C., Ottolenghi, P. \& Whittaker, P. A. (1972). Induction of petite mutants in yeast by starvation in glycerol. Biochemical Journal 127, 46-47 P.

Whittaker, P. A., Hammond, R. C. \& Luha, A. A. (1972). Mechanism of mitochondrial mutation in yeast. Nature New Biology 238, 266-268.

WhittakeR, P. A. \& Wallis, O.C. (1971). Biosynthesis of yeast mitochondria. Effects of rifampicin. Biochemical Journal 125, 82 P.

WhitTAKeR, P. A. \& WRIGHT, M. (1972). Prevention by cycloheximide of petite mutation in yeast. Biochemical and Biophysical Research Communications 48, 1455-1459.

Williamson, D. H. (1970). The effect of enviromental and genetic factors on the replication of mitochondrial DNA in yeast. Symposia of the Society for Experimental Biology 24, 247-276.

Williamson, D. H., Maroudas, N. G. \& Wilkie, D. (197I). Induction of the cytoplasmic petite mutation in Saccharomyces cerevisiae by the antibacterial antibiotics erythromycin and chloramphenicol. Molecular and General Genetics III, 209-223.

Willtamson, D. H., Moustacchi, E. \& Fennell, D. (1971). A procedure for rapidly extracting and estimating the nuclear and cytoplasmic DNA components of yeast cells. Biochimica et biophysica acta 238, 369-374. 